\title{
Geochemical characterization of groundwater from Kanpur city, India: major and trace elemental approach
}

\author{
SUKANYA ACHARYYA ${ }^{1}$, ANIRBAN DAS $^{1}$ \\ ${ }^{1}$ Pandit Deendayal Petroleum University, Gujarat, India ; \\ (sukanya.aphd18@sot.pdpu.ac.in)
}

Kanpur, a major industrial town in northern India, situated at the bank of river Ganges is famous for its leather and textile industries. In April, 2019, 34 groundwater samples and 4 alluvium samples were collected from different areas of Kanpur city. Hydrochemical facies classification based on Piper diagram [1] exhibits that $\mathrm{Mg}-\mathrm{HCO}_{3}(56 \%)$ is the dominant type followed by mixed type $(32 \%)$ and $\mathrm{Na}-\mathrm{HCO}_{3}$ (6\%) type. Based on various co-variation plots e.g., $\mathrm{Na} v \mathrm{vs}$, $\mathrm{Na}+\mathrm{Mg}$ vs $\mathrm{Cl}+\mathrm{SO}_{4}, \mathrm{Na}-\mathrm{Cl}$ vs $\mathrm{HCO}_{3}-(\mathrm{Ca}+\mathrm{Mg}), \mathrm{Ca}+\mathrm{Mg}$ vs $\mathrm{HCO}_{3}+\mathrm{SO}_{4}$ it was concluded that groundwater composition is dominated by weathering of alkaline saline soils and/or the silicates. Additionally, chloro-alkaline indices [2] point towards the ion-exchange reactions as a controlling mechanism for groundwater characteristics.

Several trace metals $(\mathrm{Cu}, \mathrm{Cd}, \mathrm{Cr}, \mathrm{Co}, \mathrm{Pb}, \mathrm{Ni}, \mathrm{Zn}, \mathrm{Fe}, \mathrm{Mn})$ were quantified using ICP-MS to learn about the possible contamination and the risk associated with the consumption of groundwater. Except for $\mathrm{Cr}(\mathrm{n}=3), \mathrm{Mn}(\mathrm{n}=8)$ and $\mathrm{Fe}(\mathrm{n}=1)$ in a few samples all other trace element concentrations were well within the permissible limit as per IS-3025 guideline, 2012.

X-ray diffraction analyses of the four alluvium samples reveal that minerals majorly falls under three groups: (i) tectosilicates (quartz, albite, anorthite, microcline); (ii) phyllosilicates (muscovite, biotite) and (iii) spinel group (chromite, crocoite). Conclusively, most of the water samples are suitable for drinking purpose but people should be alerted in the areas adjoining Khyora, Keshavapuram, Cantonment and Raniya with high trace metal concentrations.

[1] Piper, A. M. (1944). A graphic procedure in the geochemical interpretation of water-analyses. Eos, Transactions American Geophysical Union, 25(6), 914-928. [2] Schoeller, H.(1967). Geochemistry of groundwater-an international guide for research and practice (Chap. 15, pp. $1-18)$. 